$J J M L L$

\title{
Poetry and Prose and the Compound in Abu Sulayman Al-Sijistani
}

\author{
Sahar Al-Jadallah \\ Language Center, Yarmouk University, Jordan \\ Sawsan Daraiseh* \\ Department of English Language and Literatures, Yarmouk University, Jordan
}

Received on: 12-8-2020

Accepted on: 14-1-2021

\begin{abstract}
This study reveals Abu Sulayman Al-Sijistani's unprecedented approach in regard to poetry and prose and the relationship between them, allowing them to undergo logical standards by borrowing some ideas from Aristotle's books The Poetics and Rhetoric through the ancient Arabic translations, explanations, and summaries of them by Muslim philosophers. The end result is that Sijistani presented deep critical insights about the essence of poetry and prose, the functions assigned to them, and the expected results of their creative material. This theoretician also spoke of a new type of speech, which he referred to as "Almorakab Minhoma": "The compound," which was a product of his fertile thought, and which he advocated, considering it the kind of speech where preferences among writers occur, surpassing such preferences that are steered by self-interest or external social and cultural factors. With that, he recorded a quality contribution in the dialectical circle about the relationship between poetry and prose and the preference of one over the other
\end{abstract}

Keywords: Poetry, Prose, Aristotle, Sijistani, Compound.

\section{Introduction}

The issue of the relationship between poetry and prose and the preference of one over the other is one of the thorny controversial issues which have preoccupied many scholars in both old and modern times. This is due to the similarity of the language structure that they are composed of. Through mimesis, they are produced in molds and structures that determine their kinds in a way that each can perform its own function. Each genre has its own advocators and defenders who have complete persuasive evidence. However, there is no doubt about their mutual importance in terms of monitoring the intellectual heritage of any nation, registering its civilization and realizing its direction to the extent where preference between them is to be terminated. Therefore throughout the centuries, discourse has been used to discuss the advantages of each, their effective role, and methods of reading them in accordance to critical approaches which are capable of translating the human spirit as required by the nature of literature.

A researcher in this field may find many studies and researches that have traced the course of the preference between poetry and prose among the Arabs (Homami 1991; Al-Zoubi 2017). In addition to

๑ 2022 JJMLL Publishers/Yarmouk University. All Rights Reserved,

${ }^{*}$ Doi: https://doi.org/ 10.47012/jjmll.14.1.3

* Corresponding Author: sawsand@yu.edu.jo 


\section{Al-Jadallah, Daraiseh}

that, the book of Al-Imtaa' Wal-Muanasa by Abi Hayyan Al-Tawhidi (DOD 414 H./1023 AD) has abundant material about this preference as well, elucidating the arguments of poetry proponents and prose proponents (Isma'el 2003, 299-304). Tawhidi tackled this issue "in detail by collecting the opinions of literary critics, writers, poets and philosophers on this issue." (Al-Zoubi 2017, 90) The fourth century of the Hijri calendar had witnessed great activity concerning this critical issue, in which advanced critical views were crystallized due to the development of intellectual and scientific life. One of the fruits of that was the development of literary theory, and the emergence of literary models which were in harmony with this development.

The present study tries to illuminate the hidden aspects about the deep awareness of Sijistani, known as Abu Sulayman (DOD: 380 H. / 932 AD), the logical man, in these two literary genres. His awareness of the importance of the two literary genres is manifested in his analysis of both poetry and prose in terms of their essence and function; an analysis which is based on philosophical bases and logical measurements. In addition to that, this awareness is also revealed through introducing a new type of speech genre, "Almorakab Minhoma" / "The compound." It seems that Sijistani was influenced by Aristotle's books The Poetics and Rhetoric through their two ancient Arabic translations. There is no need to prove this influence, as the Arabic translations were "the seed that was dropped into the soil of Arab culture, and as a result, it flourished, grew, and bear fruit." (Ayyad 1967, 5) Joel Kraemer argues that Sijistani and his circle embraced the Aristotelian idea that "the world is striving for perfection." (1986, 152). This logically explains the influence of Aristotelian philosophy on them and their constant striving for more fulfilling and inclusive knowledge.

One of the forms of this fruit is the words of Sijistani about poetry and prose. Despite the misunderstanding that could have impeded some of what Sijistani understood about the nature of poetry and prose, we still owe to him the dividing lines between them, which depended on the philosophical statements that he gleaned from Aristotles' books. He also developed his own ideas which were the result of this influence, while molded with the nature and characteristics of Arab culture. This led him to produce a new, fertile method of thinking.

This study will not discuss the validity of the correspondence between the old Arabic translations on which Sijistani relied - that of Abi Bishr Matta bin Younes or that of his disciple: Yahya ibn Ady, and the original Greek text, because this is a matter which has taken a great deal of space in the studies of both Arab and Orientalist scholars. In addition to that, the study is not concerned in accurately tracking where Sijistani is influenced by Aristotle or those who explained Aristotle; Al-Farabi and Avicenna. The influence is clear, and it is a fruitful one in its field because it is molded with Arab cultural characteristics. However, the study is concerned with looking into the statements of Sijistani on poetry and prose and especially what he refered to as "The Compound"; hence, their importance lies in unraveling the logical figure of reference and his statements in this context, which were presented by his disciple Tawhidi and discussed accordingly. Although Tawhidi mentions that he cites from his teacher Sijistani, and the researchers mention that, however; attention paid to him has been weak, and to our knowledge there are no studies which present his critical views. 
Poetry and Prose and The Compound in Abu Sulayman Al-Sijistani

Perhaps his fame as a man of wisdom, and a philosopher prevented attention to him. On the other hand, his conference circle witnessed questions and conversations on many issues, some of which are issues in criticism and literature; Abu-Ishaq Al-Sabi (DOD: 384 H. / 994 AD), who regularly attended his conference circle, composed a treatise on "The Difference between the Prose Writer and the Poet" (Alfarq Bain Al-Motarasil Wa Al-Sha'er). Al-Tawhidi included the dialogue between Sijistani and Al-Sabi on this subject in the 65th session. Due to this letter's importance, Dr. Ziyad Al-Zu'bi investigated and presented a documented critical study of it (Al-Zoubi 2017, 79-122).

Before talking about the view of Sijistani and his original contribution to this field, a translation must be provided of him. This research will use Best Gazwinii Essay (Best Maqala Qazwini), the 1332 Persian edition from Avicenna's Library in Tehran, translated by Ahmad Louasani within literary studies. This book is one of the studies by the late figure Muhammad Qazwini, who was widely acquainted with both Arabic and Persian literatures: "He characterized a high scientific spirit and a comprehensive method in literary research or historical research in which he adopted a careful investigation and a complete in-depth study in observing the different aspects of the study, which made him in a special position among the scholars of Iran and the East in the present era." (Lawasany1960, 249)

In his translation of Sijistani, Qazwini relied on the books that have mentioned Sijistani directly or indirectly according to chronological time, which is a very precise and important observation. In one of his translations of him he declared, "He is Muhammad bin Taher bin Bahram Al-Sijistani or (Al-Sakhri) known as the logician, who lived in Baghdad, from among the most significant wise men and logicians in the fourth century Hijri; he lived between the two eras of Al-Farabi and president Sheikh Avicenna. Therefore, not only is he considered a descendant of Al-Farabi and an ancestor to Avicenna in terms of time, he is also their descendant in terms of his scientific value and honorable significance. "Adod Adawla Al-Dailamy" always showed him great honor and reverence, and in turn Sijistani placed some treatises in the name of this king. He studied science, logic, and wisdom in Baghdad at the hands of Abi Bishir Matta Bin Younis Al-Mantiqi "the Christian" and Abi Zakaria Yahya ibn Udi Al-Mantiqi "the Christian," who were among the well-known teachers of that era. As a result, his fame spread to distant regions in these sciences, and he became sought after by visitors and by those who are considered as impressive major references. As a result, his home in Bagdad was a meeting spot for wise men, logicians, and mathematicians in that era. Sijistani was the first speaker in most of these proceedings, the owner of the final statement and the obeyed leader. The wise writer Tawhidi, who was one of the most famous disciples of Sijistani and who attended all his sessions and collected 106 of them in a book titled Moqabasat. "It is possible to generally say that the era of Sijistani was most of the fourth century Hijri, from its beginnings and until its end." (Lawasani 1960, 250-52)

Ahmad Amin dedicates a chapter to Sijistani, entitled "Abu Suleiman as Portrayed by Abu Hayyan AlTawhidi" in his book Fayd Al-Khater, in which he mentions his position that may have surpassed Avicenna and Averroes. However, prestige and fame are a matter of luck that Sijitani did not have; few were those who knew him, or translated his work or gave him his due right. He says "if it were not for Tawhidi's here and there briefings of him, we would have never known him. During his time there was a 


\section{Al-Jadallah, Daraiseh}

group of philosophers and wise men in Baghdad; Muslims, Christians, and Jews, such as Ibn Zar'a, Ibn Al-Khimar, Ibn al-Samh, Al-Qomasi, Maskuya, Nazif, Yahya Ibin Uday, Issa Ibn Uday, Issa Ibin Ali and Tawhidi and others. However Sijistani was the mediator of their debates; he brought them together in achieving their goals, and in solving their problems. In addition to that, he had the final word in regard to the debates that took place between them." (Amin 2012, 283)

Then he quotes a speech by his student Tawhidi, from which he discovers Sijistani's personal qualities, saying: "He is strong in thought, but his thought accented his speech. In addition to that, he relies on the strength of his intellect more than looking up information in books, as he is more confident in his opinion than in trusting what others say, and he is strong in character making his opinion a final judgment on all that is presented to him. On the other hand, he is stingy with his knowledge; therefore, he does not mention some of it except before certain people if he must. Perhaps this explains his inactivity. Due to his beliefs about knowledge, he did not produce books which would make him popular, raise his status or immortalize his name. In addition to this, God who granted him authority in knowledge and intellect deprived him of beauty; he was blind, suffered from leprosy and was deformed. His blindness and leprosy prevented him from attending the councils of great men, princes and rulers. In that era this contact was the reason for the livelihood of scholars, ...Philosophy in particular needed the patronage of princes, and even their protection, because it was not acceptable to the common people and people like them, rather it was disliked by them. Abo Suleiman was poor, isolated coercively. He could hardly find sustenance or pay his house rent." (2012, 283-4)

This study is based on the books of Tawhidi, the disciple of Sijistani, in which he presents Sijistani's views and opinions on poetry, prose and "The Compound". No document is available besides Sewan AlHikma, which does not present the views or opinions of this scholar, and therefore the study depends on tracking the words of Sijistani in the books Muqabasat and in Al-Imtaa' Wal-Muanasa. Although Sijistani was poor, his home was a gathering place for Baghdadi philosophers. "His meeting spots were full of research and the exchange of views,....,A large part of these books have recordings of these sessions, notes on various points of view, and Sijitani's final say on certain matters."(2012, 284)

Sijistani has differed from many who have been concerned in showing the differences between poetry and prose and the preference of one over the other because he linked them to philosophy, and introduced a new mechanism in dealing with the critical and eloquent ancient Arabic concepts. In addition to that, he compared one with the other through researching their essence, and connecting this essence to the special function assigned to it. He gave his opinion on their precedence, and he explained the reasons that led to preference of one over the other according to his opinion, and he revealed a new original view in which he was considered unique in, namely "The Compound" of poetry and prose.

Sijistani took logic to be the tool that distinguishes between poetry and prose. When asked "What is logic?" he said, "A device used to separate and distinguish between what is said: is true or false, in terms of what is thought, and among what is said to be: good or evil in what is practiced, and between what is said to be: truthful or dishonest, what is revealed by the tongue and what is said to be: beautiful or ugly in actuality" (Sandooby 1991, 63). He considered logic to be not a form of knowledge, but a tool which 
Poetry and Prose and The Compound in Abu Sulayman Al-Sijistani

distinguishes between knowledge, for he "completely biases the view of Aristotle, as he does not include logic into the divisions of theoretical or practical science, and he considers it the knowledge of the laws and rules of thought regardless of the subject of thought, in other words, it is a tool for knowledge." (Zaini 2001, 3)

One could divide the issues put forward by Sijistani as recorded by Tawhidi into two sections, making them easier to deal with and to discuss in careful detail. First are the natures and functions of poetry and prose; the second is the comparison and preference between poetry, prose, and "The Compound".

\title{
The Nature and Function of Poetry and Prose
}

Sijistani begins his discussion about prose and poetry by analyzing their essence, stating, "Poetry is more indicative of nature, because poetry is from the space of structure, while, prose is more indicative of reason, because prose is from the realm of simplicity. In addition to that, we have become more fond of poetry than of prose because our nature is more in control of us than is our mind, and rhythm is loved and appreciated by nature and sense; therefore, it is needed [when] repugnant vocabulary is proposed" (Sandooby1991, 137). He also states, "Speech is uttered in its first principles either spontaneously, or by exhaustive thought, or by a combination of them, and therefore has the strength and power of both in terms of more or less; thus, the virtue of spontaneity is that it is more expressive [asfa]. And the virtue of exhaustive thought is that it is more direct $[a s h f a]$ in revealing the idea mentally. According to Aristotle prose speaks of things which have happened and focuses on reporting particulars (Butcher 1974, 11).“... and the virtue of the compound is that it is more complete $[a w f a]$ as it shares the characteristics of both. However, the shortcoming of spontaneity is that the involvement of reason is less; and that the shortcoming of exhaustive thought is that the involvement of the senses are less, and the shortcoming of the compound has to do with the amount of each in the compound: the most or the least" (Isma'el 2003, 299).

Sijistani's discussion is illustrated in the following table:

Poetry
Domain of Construction
Nature/ Senses
Spontaneity
Purer in Terms of Expression (asfa)

\author{
Prose \\ Domain of Simplicity \\ The Intellect \\ Exhaustive Thought \\ More Direct/ Unambiguous (ashfa)
}

The research presents some important words by Aristotle in this context. He speaks about what leads to poetry construction connecting that with its essence: "It seems that poetry has emerged due to two causes, both natural. Imitation (mimesis) is an instinctive behavior in human beings which appears in him since early childhood (man acquires his primary knowledge), in addition to that, people find pleasure in imitation....and another reason is that learning is pleasurable: not only for philosophers, but also for every person" (Badawi 1973, 12).

Based on the words of Aristotle, the basis of man's prowess in imitation (mimesis) in poetry is the instinct for learning, its pleasure, the path of learning, natural pleasure and feeling. This is what Sijistani 


\section{Al-Jadallah, Daraiseh}

declared in summary when he said, Poetry is more indicative of the essence, as it lies in the realm of construction which means it uses imitation (mimesis) such as simile and metaphor to produce in the recipient pleasure which is a companion of the senses. Therefore, poetry is a companion of pleasure. "The general perception of philosophers about pleasure in poetry is accompanied by their talk about mimeses; pleasure is almost adjacent to mimesis."(Abdulaziz 1984, 140) Therefore, poetry is from the realm of senses. Poetry is the companion of pleasure due to the requirements of its essence, which produces exclamations and uses imitations and rhymes, and rhythms, as Sijistani has declared, as it is adored by the essence and the senses, and this is what makes poetry an emission of and reference to essence, because the qualitative characteristic of poetry, as illustrated, is imitation (mimesis) and rhythm, and they are the companions of the senses. Therefore, poetry is from the realm of the senses. Based on Avicenna's understanding of the poetics he declares that poetry: "is the art of persuasion and statement of opinion, poetic, the art of imitation and imaginative appeal[...]the movement of poetry...is primarily imaginative, a progression from image to image determined emotionally" "(Dahiyat 1974, 46) The Romantics, particularly William Wordsworth, who worshipped poetry because it was able to express emotions in words and images about the world, defined poetry as "the spontaneous overflow of powerful feelings" (Wordsworth, ed. 2003, 8). In her speech about the philosophers' sensual presentation of the image, Olfat Abdulaziz states that "simile and metaphor are described as imaginary simulation which emanate from the imagination which in turn depends on the senses and so poetry does not work without the senses no matter how good it is at abstraction and innovation,..., philosophers insisted on the sensuality of the image in poetry because it performs the task of approximating and clarifying abstract and intangible things, i.e. approximating what is absent from the senses with what is sensory. (1984, 247-250)

As for the transmission of poetry spontaneously and its virtue due to the fact that it is asfa (purer) because it depends on the senses in conveying the idea: it makes use of the means of imitation (mimesis) as a way to do so, and so whatever the imagination of the poet falls upon in terms of metaphorical and borrowed images based on the senses, the poet brings into his work without thinking deeply or carefully because his nature chooses it, and because he wants to convey it as he feels and imagines it without having to cause deliberate change to its structure. This would mean that the poet intends to convey his speech not directly, but through representation and imitation (mimesis). And so the characteristics of poetry, which are mystery, strangeness, and the lack of conventionality, are bound to be incorporated into it because poetry is emitted from the realm of spontaneity, and therefore it is purer (asfa) due to its proximity to the senses and their direct expression of it. It is not the product of a contrivance. Therefore, poetry stimulates emotions of pleasure and satisfaction or distress in the recipient without careful consideration and thought. Explaining Aristotle's book, Avicenna (DOD: 427 H. / 1037 AD), defines poetry as

Imitated speech composed of equally rhythmic speech, and according to Arab rhyming....However a logician would perceive poetry in terms of its imitated quality. Imitated speech is that which the spirit yields to, and as a result it either becomes happy about certain issues or angry without careful consideration, deep thought, and 
Poetry and Prose and The Compound in Abu Sulayman Al-Sijistani

choice, and in general you react to it spiritually-non-intellectually....And perhaps the lie of a poet is imitated....People are more willing to imitate than to believe. (Badawi 1973, 161-2)

This is what the second teacher Al-Farabi (DOD: 339 H. / 950 AD) mentions in his treatise " $F i$ Qawaneen Sina'at Al-Shuaraa" (On the Rules of Making Poets):

Poets both have a connection and have a natural readiness to produce poetry and speak it. In addition, they have innate capabilities at producing analogy and representation: either for most kinds of poetry, or for one kind, and they are not familiar with the composing of poetry as it should be composed; However, they are limited to the genuinity of their nature and their natural readiness to what they are facilitated towards, and those are not mosaljisoon [they do not use measurements with the truth]. This is due to the fact that they completely lack complete thoughtfulness and are completely certain of the production....the best quality is what is considered an inborn characteristic." (Badawi 1980, 155-56)

This is what Sijistani meant by spontaneous production, and so there is no thought and no careful consideration of what to say, but the poem is produced due to certain attitude estimated; where utterances are switched into images, causing in the receiver psychological excitement (exciting the emotions), and not an intellectual one.

As for prose, it is more indicative of the mind, because it is from the realm of simplicity. This means that it purposefully sends utterances in a direct manner which is clear, easy, and appropriate, and it is very reasonable and logical to understand the word "realm" in the words of Sijistani to mean "style." Accordingly, the meaning becomes that poetry is from the style of composition, and prose is from the style of simplicity. These are meanings that appeared many times in two of Aristotle's books The Poetics and Rhetoric. In his public speeches, speaking about the style of prose, Aristotle declares,

One of the most important features of style is what could be referred to as clarity. It shows that, if speech does not make meaning clear, it then does not perform its own function, nor should it be less than what it actually entails, and not above the status of the subject, but suitable for it, therefore the poetic attitude may not have been low, however, it is not suitable for prose, and proper names and suitable verbs are what make style clear...because names(nouns) and verbs are the elements of speech.... Therefore we should restrain from using strange names, compound names or innovative names only rarely and in a few places.... Only sound and appropriate words and metaphors are used in prose only. (Badawi1980, 196-97)

Aristotle asserts that figurative language is equally important in both poetry and prose, but the speaker[of prose] should give it great attention, because the resources of prose are less than those of poetry. The figurative use of a word-more than any other-provides clarity, interest, and a strange imprint....But we must use suitable figurative language and features. (1980, 197-198) 


\section{Al-Jadallah, Daraiseh}

Aristotle puts forth a number of characteristics that figurative prose should have, for example, that it should not be coercive, that its content be beautiful to the ear, that it be well understood, and used economically-meaning in moderation.

Aristotle attributes the insensitive attitude of prose to a number of things. Most important is the use of complex and strange words, which include longer inappropriate adjectives or adjectives of very blended qualities, including burdened figures of speech that lead to ambiguity, which leads to the failure to convince. He also considers analogy a kind of figurative language which is useful in prose, but its use should be reduced because it has a poetic character, and the conditions that apply to it also apply to figurative language. (1980, 201-205)

Recalling Aristotle here about the style of prose is to confirm the words of Sijistani that prose is from the realm of simplicity, as it aims at stating the idea clearly, and therefore it is both more indicative of thought because it comes from careful consideration and thoughtfulness and is more effective and direct (ashfa) in terms of understanding. The idea of what is stated is acquired by the listener directly without ambiguity or displacement or representation or imitation (mimesis). Based on his reading of The Poetics, Avicenna makes a similar distinction agreeing with the formerly discussed. He refers to rhetoric as the presentation of an opinion while refers to poetry as the representation of habit. In addition to that, he describes the movement that takes place in poetry as is an imaginative one which "a progression from image to image determined emotionally" while in rhetoric the progression is from idea to idea that is determined logically (Dahiyat 1974, 46- 47).

What has been revealed previously about assigning poetry to the realm of sensibility and prose to the realm of reason is for Sijistani the axis around which speech revolves and where the basic structures reside. Therefore, any change or reversal of what has been revealed would come from strange effects of the soul and the anecdotes of the acts of nature. In relation to that he says,

It could be possible that the image of the brain in [spontaneity is clearer, and that the image of sensibility is in thoughtfulness] is more demonstrative, however that is from among the strange effects of the soul, the anecdotal acts of nature, the axis of the pillar that was formerly described, and its origin that was anchored. (Isma'el 2003, 299)

In these words of Sijistani there is an important and dangerous indication of the possibility of reversing the intrinsic nature of poetry and prose, which would mean that poetry comes from the realm of reason and prose from the realm of the senses: this would make the role of poetry persuasion or reporting and the function of prose to create pleasure and influence. But he considers this from among the strange and anecdotal issues, and so the pillar that is considered the original is what was mentioned formerly.

Sijistani argues that poetry is more indicative of the senses because it is from the space of composition, and in this is a summary of deep critical conceptions that touch the essence and reality of poetry, which is based on the composition of meaning imitation (mimesis) and simulation which are associated with the sensory. Then he places the basic element which follows (the second) to poetry, 
Poetry and Prose and The Compound in Abu Sulayman Al-Sijistani

mentioning the rhythm, which is an image of sensibility as well, because it is its beloved and is emitted from it. The word adal (more indicative of) Indicates that the creative material of poetry is based on the senses. It is a comparative word, which means that prose also has creative material, as it shares with poetry the use of senses; however, poetry depends on the senses more. And since poetry is from the realm of composition, it therefore falls in the area of ambiguity, and this ambiguity is aligned with the nature of its construction.

As for prose, it is more indicative of the intellect, because prose is from the realm of simplicity, and simplicity refers greatly to clarity, which is linked to understanding and the intellect. And the expression adal (more indicative) refers to the sharing of both poetry and prose in reference to the intellect, except that prose refers more to the intellect than does poetry.

In his previous brief opinions on poetry and prose, Sijistani reveals a new idea which is different from the conventional one in terms of how they are perceived. He defines them so their essence and true quality are not affected. In his previous opinions, he reflects a deep awareness about their essential nature and their expected goals. Sijistani discovered this information through a scrutinized logical point of view based on philosophy. He also reveals an important awareness of the relationship between a literary text and its receiver, which emanates from the nature of the creative material of both poetry and prose.

The understanding of Sijistani is advanced, hardly in contrast to the modern critical conceptions in the East and the West in terms of the structures of poetry and prose. This is not difficult to explain; for the source which influenced both the old critics and the modernists equally is the same: the books of Aristotle generally, The Poetics and Rhetoric especially what they left behind were explanations and summaries and new perspectives, which were the result of that influence. And perhaps Arabic criticism's concern with the explanations of philosophers-like Farabi, Avasinna and Ibn Averroes (DOD: 595 H./ 1198 $\mathrm{AD}$ ) - and their summaries, as well as the writings of literary figures and the Arab rhetoricians in the fourth century Hijri and following—such as Abdulqaher Jurjani (DOD:471 H./ 1078 AD) and Abi Helal Al-Asqary (DOD:395 H./ 1005 AD) - left this figure and his deep opinions unnoticeable in this field. However this does not diminish in any way the value of these ideas and their ability to influence critical perceptions. Sijistani's circle would be replete with great scholars, wise people, logicians, critics and others. For example: Abu-Is'haq Al-Sabi, in his aforementioned treatise written after he debated Sijistani, confirms Sijistani's idea of the clarity of prose and the ambiguity of poetry and considers it to be the essential feature that distinguishes one from the other (Al-Zoubi 2017, 91).

Modern Criticism does not contradict what Sijistani said about the truth of the nature of poetry, "Rhetorical images are not merely extra ornamentation, but rather are a means to form the essence of poetic art itself, as it is what loosens the poetic load that the world conceals, that load that prose keeps captive to." (Cohen 1986, 46)

The interest in philosophy was an urgent necessity for both the critic and the writer, and this attention left its obvious effects in criticism and literature. In the seventh century Hijri, Hazem AlCarthagini (DOD: 684 H./ 1211 AD) comes very close to the opinions of Sijistani when he bases simulation, which is the substance of poetry and its qualitative description, on sensuality: 


\section{Al-Jadallah, Daraiseh}

What man understands with senses is what he imagines because simulation is a sub joint of sensibility, and whatever you understand without the senses, thus, it is lent to simulation which becomes proof of its condition or what surrounds its condition and is essential to it [to use sensual means to express what is not sensual], where those conditions are among what could be felt or seen. (Ibn Al-Khawja1981, 98)

The words of "Hazem Qartajani" reveal him to be influenced by those who explained Aristotlewho perceives poetry as

Not addressing the intellect, but addressing the imagination so it evokes the sensual images which are stored in it, and because in Aristotle, the imagination faces the power of sensation, so simulation depends on tangible items; and because they are strongly connected to emotions, it is influenced by it and influences it-poetry strongly moves the emotions. (Ayyad 1967, 257)

The connection between imitation (mimesis) and simulation, which are the foundations of poetry and its intrinsic structure, and the idea of the sensory, is a reflection of the demands of Aristotelian philosophy and the measurements of logic on Arabic critical thinking. Sijistani has summed up his previous opinions, greatly attaining his objective by defining poetry and prose through analyzing their essential nature and their emanating purpose, preceding Hazim and other critics in what he has mentioned. However, his speech came in a measurable, logical way, which did not attract much attention, and so the person to be credited for recording and verifying his opinions is his honest disciple Tawhidi who was characterized by this "mental thirst that motivated him to question himself and to ask questions about the problems that would face both his mind and soul. Among the most important problems that crossed both his mind and the minds of the thinkers around him was the problem of the relationship between poetry and prose and whether we can prefer one over the other. The origin of this problem is philosophical in nature. The strange thing is that during Dr. Abbas' speech about Tawhidi, he includes Sijistani among those who preferred prose over poetry. He says: " [This] logical man was among those who preferred prose. Their arguments vary between superficiality and depth." (Abbas1993, 221) Although he cited many of Sijistani's sayings, he did not analyze any of their details. He merely said: "The concept of composition and simplicity, or abundance and unity ...was what terrified him every time he was asked about his perception of the effect of poetry and prose."(1993, 222)Then he spoke about Abo Ishaq Alsabi's treatise which was about the difference between the poet and the prose writer. He concluded by saying: "For the first time, we find a critic who evaluates the difference between poetry and prose on the basis of the difference between ambiguity and clarity." (1993, 223) In reality Abo Ishaq had a conversation with Sijistani about this issue where the interlocutor was Abo Ishaq and Sijistani was the respondent. By looking carefully at the entirety of his views and examining them, we reach a single, accurate critical perception based on determining the nature of each of these two arts, and the function or purpose that follows them. 
Poetry and Prose and The Compound in Abu Sulayman Al-Sijistani

\section{Comparison between Poetry, Prose, and "The Compound"}

Poetry and prose are well-known kinds of speech, so what is this "compound"? Perhaps tracing the words of Sijistani in both books of Tawhidi in a precise way would help in discussing the opinion of Sijistani in the issue of the comparison between prose and poetry, and which of the two he favors. It also helps in revealing what is meant by "The Compound".

Once his disciple Tawhidi told him, “Abu Ishaq Alsaby has classified a letter in comparing prose and poetry."

Sijistani replied, "He has asked me about them a few days ago and so I told him that prose is more honorable in its essence, and poetry is more honorable in term of its display."

Tawhidi then asked, "And how is that?"

Sijistani said, "Because unity is more in prose, and prose to unity is closer. And so the rank of poetry is below the rank of prose, because unity receives precedence and what follows it is secondary."

Tawhidi asked him, “Why doesn't prose musically delight as poetry does?

He said, "Because we are systematic, and so what suits us delights us, because the image of unity in us is weak and our distance from unity is far away, and so if we sing we sway, that's what mostly, and more generally happens, or in most people. In addition to that, we may also find in ourselves such a delight, comfort, euphoria and swaying in a chapter of prose and what guides to this which we have supported and the meaning that we have chosen, is that the heavenly books were articulated in words of prose, and famous doctrines, even he who was chosen to carry the heavenly message at the end was more inclined to that type of unity, and so he did not compose on his own, and he could not, and he did not tell people, about divine power through that known method, but rather he was above that, and instead he was concerned in displaying what they were used to and familiar with, in a way that baffled every listener, cooled down the grudge of every listener, guided every stray person, straightened every stubborn person, benefited every intelligent person, created every student, drove away every biased person, guided every lost person, lifted every confusion, explained every problem, spread all knowledge, led every stray, and suppressed every bad person. This does not happen, and should not be except in the suitable person who qualifies to compose the word of prose. (Sandooby 1991, 153-4)

In contemplating the words of Sijistani, it appears that he does not favor any one of them over the other, and so he does not prefer prose over poetry, nor poetry over prose, even if sometimes it seems that in some areas that he is more in support of prose; however, his preference appears to be mentioned in the context of his conversation about the reasons for our assignment of rhapsody to poetry, not to prose, yet 


\section{Al-Jadallah, Daraiseh}

he does not assign rhapsody to poetry only, because this characteristic may be available in prose as well. The proof is that the heavenly books appeared in words of prose which people were used to and were familiar with, but they were received in ways that baffled every listener and quenched the thirst of every listener.

Sijistani's linking of prose and its excitable efficacy in rhapsody confirms that he does not favor either one; however, he sees that each of them is committed to its own specific duty, and if done properly, progresses. In his speech about the heavenly books, particularly the Qur'an, the functional characteristics he assigned to it were derived from its own essential nature as a prose text, and the axis of these characteristics is understanding, science, and explanation, which refer to the intellect. But the hypothetical urgent question here is: Why do the prose heavenly books influence both minds and souls together? And in another perspective, Why do poetry and prose practice both influence and persuasion? And in a third perspective, Why are we driven towards a certain prose text and not another?

The answer to these questions in their many forms comes after analyzing the former words of Sijistani:

"Prose is most honored in terms of essence, and poetry is most honored in presentation," he said.

"how is that?" I asked.

"Because the angles in prose are more, and that prose in terms of its unity is closer.

And so the rank of poetry is below that of prose, because unity receives precedence and whatever follows is secondary."

meant by essence: thought, intellect, substance, and meaning, and by presentation he meant attitude, form and image, and he singled out prose with essence, because it is closer to unity, and it resides in it the most. About unity he declares that it

is the point that does not have a certain position, and the point is a unit which does not have a position. And so unity is the standard of oneness, and it is the separate amount of the status of a number which is combined of units and which meet without any contact with one another. $(1991,171)$

Since unity is first, and prose is closer to it, it receives precedence, and its status is higher than the status of poetry. This is a mental judgment in which Sijistani adopted logical analogy, but it does not carry the meaning of preference in terms of what the term preference means. However, by it he meant the priority of the need to speak. He declares, "The need to speak in general is more important than the need for eloquence, because the former is primary, and the latter is secondary" (1991, 63). The meaning of this distinction is made clear when he writes,

The limit of getting another to understand and understanding is known, and the limit of eloquence and rhetoric is described, and the need to get people to understand and understanding according to linguists (the people of the language), is more greatly needed than the need for rhetoric and eloquence, because it is primary, necessary in terms of nature, and nature is closer to us, and intellect is farther away 
Poetry and Prose and The Compound in Abu Sulayman Al-Sijistani

from us, and intuition is derived from the senses, even if it were assisted by the sensory, and it should not be acceptable to make matters understood however, and in whatever way. (1991, 62)

Sijistani explains that the reason for our delight in poetry is that we are systematic. Thus, poetry is systematic, and therefore man is inclined towards what looks like him, because he is more for essence and sensation than he is for the mind, and so the image of unity in us is weak, and our relationship to it is distant. On the other hand, unity is abundant in prose, and therefore people are ruptured by poetry. Here is a dangerous hint by Sijistani of the possibility of rupture by prose texts, and his evidence is the heavenly books. Therefore, he does not favor either one. He declares,

The intellect necessitates meaning, and so no word receives favor with him, even if it were an excited admirer. And proof that meaning is an essence request without rhyme; without feigning it and without making it a necessity; which means that when meaning is portrayed as favorable and desirable and is carefully constructed, fearing judgment, it does not do so well in revealing its powerful pronunciation, which to it is like its clothing, its exhibition, container and envelope. However, with that in mind, the mind makes continuous choices between words, loves an image and doesn't another, and connects with one rhyme and does not with another, and that is why speech is divided into kinds of prose and classes of poetry. And is that not for nature? Rather, it relies on what is pleasant to the ear, light on the heart, between it and the truth is a connection, and between what is right and it a relationship, and its judgment is mixed with the dictates of the soul, and the acceptance of the soul is due to the intellect's role as a corrector. $(1991,137)$

This rhetoric is very accurate and moderate in terms of perspective. It is important because it puts the suitable joint in the comparison, and as a result, poetry is not better than prose, nor is prose better than poetry, but the best is what has achieved its essence, performed its function, and fulfilled its conditions. Even if the mind demands meaning only, yet it chooses a certain expression and not another, and associates with a certain rhyme and not another, loves a certain image and not another. As a result there are preferences between prose texts as well, and so not every prose text which fulfills its meaning is in an advanced position. The same goes for poetry; the best among its kind is what is beautiful to the ear and light on the heart; between it and authenticity is a connection, and between appropriateness and it is a relationship. What is interesting is what Sijistani sets afterwards as a logical standard in accepting the two types of speech: poetry and prose. This means that the essences' judgment is mixed with self-dictation, and that self-acceptance is due to the mind's capability to correct. According to Dahiyatat, Aviccena approached the two arts in a manner that "in which the two arts were thought to hold some vital common ground, both in terms of their use of the devices of eloquence such as metaphor and the other figures of "thought" and "speech" and with regard to the notion that poetry, in a way analogous to the "branch" of rhetoric that Aristotle calls "epeideictic"(Dahiyat 1974, 46)

This is a criterion that has depth of vision and rationality in measurement, and it is a sign of anticipatory awareness in this man's outlook, for essence does not provide its judgment on speech unless the self-accepts it, either by acceptance or constriction, meaning being excited, which on the other hand is due to the mind correcting these words, because the connection between them is very strong and deep. 


\section{Al-Jadallah, Daraiseh}

This is a prelude to what Sijistani makes clear afterwards when he declares,

Yet, in prose there lies the shadow of poetry, and if it weren't for that, it wouldn't be light, nor beautiful nor would it be pleasant nor would it be primped. And in poetry there is a shade of prose, and if it weren't for that, its different structures wouldn't be unique, nor would its supplies and resources be delightful, nor its meters and methods, nor were its connections and particles be concordant. (Sandooby 1991, 137-8)

Perhaps these words of Sijistani are made clear by his words in Al-Imtaa' Wal-Muanasa about "The Compound". He declares,

Speech is emanated in its first principles either from spontaneity, or from deliberate thoughtfulness, or [it is] a compound, which has their power of more or less, and so the virtue of spontaneity is that it is clearer and more direct, and the virtue of deliberate thoughtfulness is to be more effective, and the virtue of the compound is to be awfa (more complete). In addition to that, the shortcoming of spontaneity is that the image of the intellect is less; and the disadvantage of deliberate thoughtfulness is that the image of the senses is less. On the other hand, the disadvantage of the compound has to do with how much each of the two characteristics is included: the majority and the least, but if this compound gets rid of the impurities of artificiality, and the evils of arbitrariness, it would be eloquent, acceptable, fabulous, beautiful, embraced by the breasts and listened to by the ears, and symposiums would discuss it thoroughly due to its high value, in which rivals would use it to compete one after the other, and the comparisons which reside among rhetoricians about poetry and prose are both in the compound which is referred to as prose and poetry. (Isama'el 2003, 299)

The meaning of Sijistani's words in "Moqabasat" is that prose can include some contents of poetry, and poetry can contain some of the contents of prose, with the condition that the senses in poetry must be more than that of the intellect, and that the share of the intellect in prose is more than the senses; so that neither one would lose its unique qualitative quality, as stated in Al-Imtaa' Wal-Muanasa. This is very close to what Abdel Aziz concluded in her talk about the language of poetry and the language of prose according to the Muslim philosophers, she says: "The philosophers concluded that the difference between prose and poetry in the use of poetic language is a quantitative and qualitative difference, as it is stipulated that the speaker does not use lots of changes, and that he uses what is far from ambiguity and strangeness. The reason for this is that prose aims to achieve a good understanding and a decent amount of pleasure, while poetry aims at simulation... based on this; the philosophers assert that the poetic function of a language is achieved outside poetry itself, they also assert that there is a big difference between its realization outside of poetry—as is the case in public speaking and prose in general—and its realization in poetry. This is because it remains a secondary function in prose, while in poetry, it is achieved in a high degree of quantitative and qualitative intensification; it becomes the dominant and predominant element in it." (Abdulaziz 1984, 209-10) This is not far from what Cohen said: "The difference between poetry and prose is more quantitative than it is qualitative. Rather, these two literary genres are distinguished by the abundance of displacements, and the difference in this quantity can be 
Poetry and Prose and The Compound in Abu Sulayman Al-Sijistani

reduced to the least possible .... and there appears to be no poem of a hundred percent poetry."(Cohen 1986, 23)

A table for poetry and prose which incorporates "The Compound" follows here:

\section{The Compound of Poetry and Prose}

Contains both the Power of Poetry and the Power of Prose

Structure and Simplicity

Senses + Intellect

Spontaneity + Laborious Thought

More Complete (awfa)

One could say that compound speech is speech in which the forces of prose and poetry unite and appear to be stronger than either one on its own. Sijistani advocates for this kind of speech, which he really considers to be from his own thought and deep understanding. And he refers to its virtue by saying that the virtue of the compound of them is to more complete $(a w f a)$, combining the serenity and clarity of poetry and the affectivity and directness of prose, the serenity of nature and sense, the affectivity of understanding and reason. As for its flaw, as he puts it, it is the inclusion of each in the compound: the majority and the minority. That is, if speech is poetic, the power of poetry is to be more evident, and if speech is prosaic, the forces of prose are to be more accentuated; if one's power overwhelms the other, a defect enters, and if it is as mentioned, it may happen, but it would be considered to be among the strange relics of the soul, and the anecdotes of the effects of nature.

Perhaps the authenticity of Sijistani in his thought here is reflected in "The Compound," which he considers the purpose of speech: the perfect image of expression, provided artificiality and discreditability are gotten rid of. That is, the force of one of them does not appear in a way that is intentional, exposed, or ill, and if the "compound" Is purged of this defect, the result is eloquent, acceptable, and sweet speech that achieves many functions, not only one.

Sijistani simplifies and clarifies the matter by discussing the impact of this type of speech on his recipients:

1. It is embraced by the breasts: the speech reaches the heart, causing a pleasure that sticks to the speech.

2. It is secretly listened to: it has a sweetness upon hearing which causes rapture and admiration.

3. Symposiums lovingly discuss it: that is, it is discussed among people because they prefer it and they are fluent in it.

4. Competitors use it to compete with each other: in it, preference resides, as it is the best image that writers seek.

Sijistani reveals that he is in support of this kind of speech and prefers it by saying: "The preference that happens between rhetoricians between poetry and prose, it is, however, in this compound, which is named composition and arrangement (meaning prose and poetry)." He also sets important criteria for how to construct this type of speech:

Reasonable meanings are simple in the realms of the soul. Nothing hovers over them before thought, if thought finds meanings in the strong confident mind and a careful 


\section{Al-Jadallah, Daraiseh}

understanding, it would cast that into the phrase, and as a result the expression would be composed between rhyme which is the composing of poetry, and between a rhyme which is the context[prose speech]; all that is due to a correct or corrupt ratio, a beautiful or ugly image, an acceptable or undesirable composition, good or bad taste, an easy or lame way, a strong preferred brevity or a repelled weak one, an absolute or weak argument which is not rejected and noticeable or disclosed proof, a distant or close topic, and a familiar or strange audible. (Isma'el 2003, 304)

Sijistani tracks the creative process of building speech from the moment it has meaning in the soul, and reasonably clear meanings are available in every soul which nothing affects before thought, and this is exactly what he means when referring to the high level of prose: he means that meanings are first, because they are closer to unity, and poetry is farther away, so poetry is second, and then comes the composition phase for both poetry and prose.

Sijistani sets ten important criteria in the construction of speech, whether it is poetry or prose, which makes it a wonderful compound:

1. The correct or corrupt ratio. This refers to the proportion of sensation in poetry, and the proportion of reason in prose, and if the proportion of thought increases in poetry, it is damaged, and if the proportion of sensation in prose increases, it is damaged, and so the author must envisage the correct amount in the construction of his discourse.

2. The beautiful or ugly image. This refers to the overall form of speech, and the definition of the word image is extensive. Perhaps it means the methods of imitation/mimesis and simulation of analogy, metaphor, imagery, etc. Therefore, the image has to be beautiful, not ugly.

3. Authoring acceptable or unacceptable compositions. The word compositional has a broad significance. It could mean subjoining an idea to another or an image to another, or uniting the form with its significance, or it could mean the relationship between the text and its recipient, so the authorship must be acceptable and not hateful.

4. Sweet or bitter taste. The word taste refers to the power of a hidden sensation capable of choosing in consistency with nature, so that taste is beautiful and palatable and not hated because it is bitter.

5. The easy or difficult route. The word route here refers to the attitude that the writer has as he seeks to communicate his idea. There are easy methods and rough or difficult ones. He has to take the path that best conveys meaning, and that is what is meant by easiness. The word roughness here carries a negative connotation

6. Preferred or repelled brevity. The word brevity here means conciseness, and preferred means nondemeaning according to the rule that says, "The best words are those which are less and indicate meaning." So words meet the meaning and do not decrease meaning or increase it, and other than that, brevity is rejected.

7. The effective and the ineffective argument: The word argument refers to the statements that the writer makes to prove his point of view. The word effective means definite, substantiated, and admissible. 
Poetry and Prose and The Compound in Abu Sulayman Al-Sijistani

8. The revealing or dark proof. The word proof here refers to the evidence that the writer brings. It must be clear and precise not unclear or vague.

9. Far or near issue. This means that the meaning and style of speech is either common or not. The purpose and style of speech in terms of its distance, whether far or near, ranges according to the style of the writer and the recipient of the text.

10. The familiar or strange audible. This refers to the effect of speech on the hearing and the heart: either it is familiar, which is close to the senses, or it is strange to them and the senses do not know it and are not amused by it.

These criteria are valid for judging and evaluating any text produced, whether poetry or prose, and thus it is clear that Sijistani does not favor either poetry or prose, but rather, he is in favor of "The Compound" provided that it achieves the criteria. He insists on this position:

If it is in this case as described, then prose has its undeniable virtue, and poetry has its honor [, which] is neither unchallenged nor covered, because prose's commendable characteristics[are]in comparison to poetry's commendable characteristics, what is considered essential for both is the achievement of integrity and precision, the avoidance of difficulty, and to interpret and clarify what needs interpretation and clearance. $(2003,304)$

Speech which is the compound of poetry and prose performs a dual function in influence and persuasion, and in terms of pleasure, deliverance, and causing understanding.

Perhaps the wisdom of Sijistani's favoring this kind of compound speech lies in his words quoted earlier: "Yet in prose the shade of poetry resides, and if it weren't for that, it wouldn't be calm or pleasant, or purposefully make beautiful." If prose were to contain solely its characteristics, and its strengths and mechanisms which focus on thought, it would be converted into a rigid monotonous text that is rejected and hated by the souls. So the presence of shades of poetry in it makes it more ornamental, acceptable, and light to the ear and heart. He also says, as also noted previously,

"In poetry, there is a shadow of prose, and if it weren't for that, its forms would not have been unique, and its sources and resources would not have been delightful, nor its rhymes or attitudes, nor would its connectors and rations accord" (Sandooby 1991, 137-8).

Therefore, poetry is unique in terms of its characteristics and its strengths and mechanisms, which focus on the senses, which changes it to a text that may be boring and loathed by the self. However, the presence of the shades of prose in it increases its fertility in thought, and it works at synthesizing its relations and strengthening its connections. In summary, neither can manage without the other in its construction. They are better together than if either were alone with its individual characteristics and powers.

And what Sijistani invites us to and supports of compound speech we find available in the literature of Arabs, both poetry and prose, and therefore we find texts of poetry and prose which are still able to enchant us despite the passage of time because they meet the criteria set by Sijistani. Due to the 


\section{Al-Jadallah, Daraiseh}

availability of the criteria set by Sijistani in them. As for the popularity of either poetry or prose over the other at a particular time in the long history of Arab literature, this is because

the difference in time and its hierarchy requires from its different levels different stages of writing, where each time a particular stage requires a kind of writing that suits its mechanisms and developments, taking into account the transformations and multiplicity of the language itself,...the factors that change rhythm and the additions that occurred to it,...the change of cultures, and the succession of civilizations and ages, and the change in the system of government....All of this has led to the need to change the written action (aesthetically) to reach the most in line with the current time phase. (Abduljalil 2000, 51-52)

Depending on an analysis of the style phenomenon by Jean Cohen in his book The Structure of Poetic Language, Yasser Mustafa presents his diagram of it, transforming the poles of the straight line into prose and poetry:

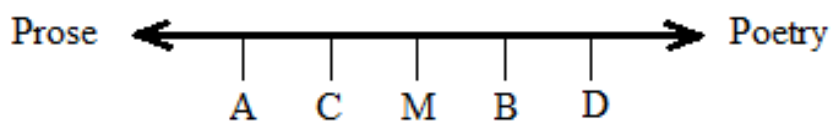

On the straight line which represents the method, point "A" gets closer to the prose pole, and as a result, the written stage here becomes of prosiac nature, while the point " $\mathrm{D}$ " gets closer to the poetic pole and so the written stage here becomes of poetic nature, and perhaps the point " $M$ " is the most important point because it represents the balance and the equality between prose and poetry, the two elements seem parallel, on the other hand, the points ("B,C") vary in terms of their poetic or prosaic qualities depending on their proximity or distance from the prose and poetic poles, and I think I can confirm that based on the above that the poem in particular is a mixture of prose and poetry together (prose mechanisms and poetry mechanisms. (2000, 52-53)

With his brilliant thinking of "The Compound," Sijistani confirms the need of man for both poetry and prose. Society too is in need of both the poet and the prose writer together, and so here moves the subjective charges of criticism that have blurred the visions of many in finding out the truth due to the preference of one type of writing over the other. (Homami 1991, 11)

The faithful disciple of Sijistani, Tawhidi, concludes his statement on the matter by saying, "In general, the best words are those of soft expressions, whose meanings are good, and whose beauty has been brightened, and its image has been carried out, between poetry as if it were prose, and prose as if it were poetry." (Isma'el 2003, 309) Homami attributes the position of Sijistani's disciple, Tawhidi, after pointing out that his declaration is based on the words of Sijistani, "to Tawhidi's mental culture, his strong connection to logic, and to the development of literary theory itself." (Homami 1991, 12) 
Poetry and Prose and The Compound in Abu Sulayman Al-Sijistani

Homami attributes the popularity of prose over poetry or vice versa over the first eight centuries of the Hijri history, beginning with the Qur' an and ending with "Sobh Al-A'sha" by Al-Qasshandi, to the outside stampedes that actually existed in reality and transformations that have included economics and social sciences. It also included thought and culture; the research denies that the comparison/preference were the result of conflicts which were governed by subjective and arbitrary considerations (1991, p. 8).

We do not think that in his discussion of "The Compound" Sijistani means establishing a truce between them, as the researcher Homami understood. However, he means the kind of speech in which the forces of poetry and the forces of prose are available in certain proportions. Therefore, one would be directed towards speech that achieves the will of man and his awareness in terms of expressing his existence, whether poetry or prose; the need generates the form. And so the written form, whether it is prose with or without the shadow of poetry, or poetry with or without the shadow of prose, ought to both perform its own function in the best possible way.

We can say that Sijistani has made a contribution and a difference in the history of literary criticism by reaching this fair view in the comparison between prose and poetry and considering them the two main pillars in the expression of the existence of man; his will and awareness. The preference of either one is the result of their fulfilling the rules of literary writing and taking into account their necessary mechanisms for performing their own functions. There is no prejudgment of the preference of one over the other: whichever has the attributes and standards presented by Sijistani is the best, and that is by including the mechanisms of the other in certain proportions which keep each of them in its own circle and does not take it out of it, so that prose remains prose and poetry remains poetry. This is what he called "The Compound" and for which he was an advocate.

This was explained by the fact that if speech were poetry and, were completely composed of the forces of poetry, it would be shallow, and if speech were prose and were completely composed of the forces of prose, it would be boring and heavy on the ear and heart. The intertwining of different mechanisms gives speech ambience and acceptance, and it distances it from boredom and alienation, and this is under the condition that the mechanisms of poetry do not dominate the mechanisms of prose if the words are prose, and the mechanisms of prose do not overwhelm those of poetry if the speech is poetry.

Sijistani's emphasis on this interaction between poetry and prose, and the acquisition of one from the other, refers in one aspect to an important critical issue, namely, intertextuality, when he says, "And its resources would not be pure." Poetry derives a great deal from prose from stories, proverbs, history, judgment and ideas, employing them in poetic ways to be richly fertile, not relying solely on its music and mechanisms. So, poetry is indispensable from prose if prose is to be lush, controlling, carrying, and referring to meaning, and prose is indispensable from poetry if poetry is to be light on the heart and the ear, distinguishing it from the dry scientific speech that the soul quickly hates and therefore rejects.

\section{Conclusion}

It is clear that Sijistani had proactive awareness about prose and poetry. The words of Sijistani are an indirect answer to the opinions of Arab and Western critics who did not consider them two art forms; they 


\section{Al-Jadallah, Daraiseh}

were accused of mashing and mixing the two forms of art. Sijistani however, considered them independent art forms, each having its own characteristics, mechanisms, and strengths. And therefore, he does not prefer one over the other. However, he does advocate for their compound, so that speech could be effective, referring, and convincing to the reader. These statements which Sijistani revealed are considered advanced critical perceptions by a philosopher, a Wiseman, and a logician who lived in the fourth century Hijri.

Sijistani does not include any kind of personal or external social or cultural considerations or any other which would force a bias on the exclusive basis of the shape of the speech. And therefore the shape which expresses better the presence of the human being, his awareness, and his soul, with mutual mechanisms and the strengths of both genres and in certain proportions is what he advocates.

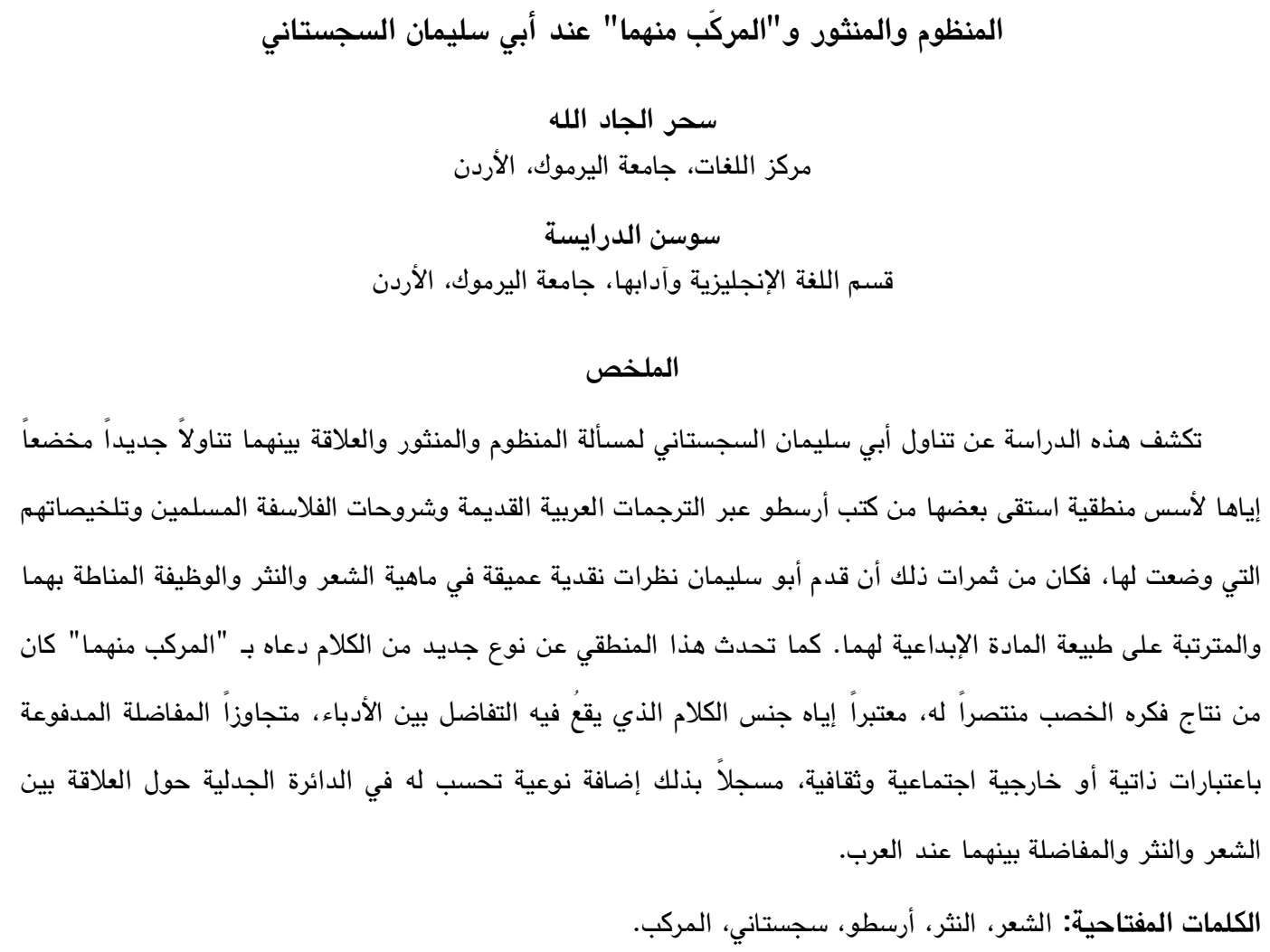


Poetry and Prose and The Compound in Abu Sulayman Al-Sijistani

\section{References}

Abbas, Ihsan. 1993. Tareekh Alnaqd Aladaby Ind Alarab. Naqd AlShi'r Min Alqarn Althani Hata Alqarn Althamin Alhijri. The History of Criticism According to the Arabs. The Criticism of Poetry from the Second Century until the Eighth Century Hijri. Amman: Dar Al-Shorouq.

Abdulaziz, Olfat. 1984. Nazariat Alshi'r Ind Alfalasfa AlMuslimeen min Alkindi Hata Ibn Rushd. The

Theory of Art According to Muslim Philosophers from Kindi until Averroes. Cairo: The Public Egyptian Agency for Books.

Abduljalil, Yasser. 2000. Alnathr Awal Alsh'er. Prose is the Beginning of Poetry. Poetry 99: 49-53.

Ahmad Amin, 283-92. Cairo: Hindawi Center for

Education and Learning.

Amin, Ahmad. 2012. "Abo Sulayman Almantiqy Kama Yosawiroh Abo Hayyan Al-Tawhidi". "The Logician Abo Sulayman as Portrayed by Abo Hayyan Al-Tawhidi". In Faid Alkhater, ed. Ayyad, Shukry, trans. 1967. Aristo Fi Alshi'r. Aistotle's Poetics. Cairo: Dar Al-Katib Al-Arabi.

Badawi, Abdul Rahman, trans. \& ed. 1973. Aristotalees Fen Alshi'r. Aristotle's Poetics. Beirut: AlThaqafa.

Badawi, Abdul Rahman, trans. \& ed. 1980. Alkhataba li Arosto. Aristotle's Rhetoric: Baghdad: Dar AlRasheed.

Butcher, Samuel. trans. \& ed. 1974. The Poetics of Aristotle. New York: Dover Publications. https://www.gutenberg.org/files/1974/1974-h/1974-h.htm

Dahiyat, Ismail.1974. Avicenna's Commentary on the Poetics of Aristotle. Leiden, Netherlands: E.J. Brill.

Homami, Al-Taher. 1991. Dalalat Almofadala Bayn Alsh'ir a Alnathr Ala Doroob Min Altahawolat Fi Almojtama' Alarabi. The Significance of the Preference between Poetry and Prose on the Kinds of Changes in Arab Society. Al-Masar 11: 8-14.

Isma'el, Muhammad Hassan, trans. 2003. Al-Imta'Wal-Mo'anasa by Abo Hayyan Al-Tawhidi. Beirut: Dar Al-Kotob Al-Ilmia.

Kraemer, Joel. 1986. Philosophy in the Renaissance of Islam: Abu Sulayman Al-Sijistani and his circle. Leiden: E.J. Brill.

AlQartajanni, Hazem. 1981. Minhaj Al-Bolagha Li Abi Hazem Al-Qartajanni. Abo Hazem Alqartajanni's The Curriculum of Rhetoricians. ed. Muhammad Alhabeeb Ibn Alkhawja. Beirut: Dar Al-Gharb AlIslamy.

Wali, Muhammad and Muhammad Omary, trans. 1986. Bonyat Allogha Alshi'riya by Jan Cohen. Jan Cohen's. The Structure of Poetic Language. Casablanca: Tobaqal Press.

Lawasany, Ahmad, trans. 1960. Abo Sulaiman Al-Sijistani wa Ketaboh Sewan AlHikma. Abo Suleiman Al-Sijistani and his Book Sewan Al-Hikma by Muhammad Qazweeny. Al-Dirasat Al-Arabia 2: 249274.

Sandooby, Hasan, trans. 1991. Moqabasat by Abo Hayyan Al-Tawhidi, Tunisia: Dar Al-Ma'aref. 
Al-Jadallah, Daraiseh

Wordsworth, William. 2014. Lyrical Ballads with other Poems. ed. Jim Manis. Pennsylvania: Pennsylvania University Press. https://spensabayalibrary.files.wordpress.com/2016/04/lyricalballads.

Zainy, Muhammad. 2001. Mawqif Abo Sulaiman Min Oloom Asreh. The Position of Abo Sulaiman Sijistani from the Sciences of His Generation. Abhath Al-Yarmouk 17: 1-42.

Al-Zoubi, Ziad. 2017. Resalatan Min Alturath Alnaqdi Ind Alarab:Resalat Abi Ishaq Alsabi fi Alfarq Bayn Almutarasil wa Alsha'ir. Two Letters from the Critical Heritage of the Arabs, The Letter of Abo Is-haq Al-Sabi on the Difference between the Prose Writer and the Poet: A Study and an Investigation. Amman: National Jordanian Library.

Note: All the quotations in the Arabic References were translated into English by the authors of the research paper.

Abbreviations:

DOD: Date of Death.

H.: Hijri (the era used in the Islamic lunar calendar) 